\title{
Breve Histórico da Educação Ambiental, sua Adoção no Ordenamento Jurídico Brasileiro e Possíveis Reflexos das Atuais Mudanças Políticas
}

\author{
Brief History of Environmental Education, its Adoption in the Brazilian Legal Order \\ and Possible Reflections of Current Political Changes
}

\section{Breve Historia de la Educación Ambiental, su Adopción en el Ordenamiento Jurídico Brasileño y Posibles Reflexiones de los Cambios Políticos Actuales}

\author{
Karina Gomes Cherubini ${ }^{1}$ \\ Rubens Jesus Sampaio ${ }^{2}$ \\ Paulo Sávio Damásio da Silva ${ }^{3}$
}

\begin{abstract}
Resumo
Este trabalho apresenta uma retrospectiva da história ambiental, desde o surgimento da humanidade e de suas primeiras intervenções significativas na natureza, até seu posicionamento como força de igual magnitude às forças naturais, com possibilidade de inaugurar uma nova época geológica, denominada Antropoceno. Em sequência, são descritas as principais conferências internacionais de meio ambiente e seus efeitos sobre o sistema legal brasileiro. Efetua-se uma reflexão sobre o cenário político brasileiro, procurando desvendar como ou o quanto as recentes estruturações no Ministério do Meio Ambiente comprometem a educação ambiental e, se vislumbrado retrocesso do tema, como e quantos anos de evolução e impregnação de um conceito foram comprometidos. Investiga se há correspondência entre o discurso internacional sobre a educação ambiental e o cenário pátrio, mediante sua inserção destacada na legislação e garantia orçamentária para a execução de seus programas e projetos.
\end{abstract}

Palavras-chave: Antropoceno. Holoceno. Legislação Ambiental. Meio Ambiente. Políticas Públicas.

\begin{abstract}
This paper presents a retrospect of environmental history from the emergence of mankind and its first significant interventions in nature, to its position as a force of equal magnitude to natural forces, with the possibility of inaugurating a new geological epoch, called Anthropocene. In sequence, the main international environmental conferences are described together with their effects on the Brazilian legal system. A reflection is made about our national political scenario, seeking to unravel how or how much the recent changes in the Ministry of the Environment compromise the environmental education. When any retrogression of the theme was perceived, we tried to estimate how and how many years of evolution and impregnation of a concept were compromised. Finally, we verify whether there is a correspondence between the international discourse on environmental education and our homeland scenario, through its prominent insertion in the legislation and budgetary guarantee for the execution of programs and projects on this subject.
\end{abstract}

Keywords: Anthropocene. Holocene. Environmental Legislation. Environment. Public Policies.

\section{Resumen}

\footnotetext{
${ }^{1}$ Mestranda em Ciências Ambientais pela Universidade Estadual do Sudoeste da Bahia, campus Itapetinga. Promotora de Justiça do Ministério Público da Bahia, Vitória da Conquista. E-mail: cherubinik@ @otmail.com ${ }^{2}$ Doutor em Desenvolvimento e Meio Ambiente pela Universidade Estadual de Santa Cruz - UESC, Professor Adjunto do Curso de Jornalismo da Universidade Estadual do Sudoeste da Bahia- UESB e do Programa de PósGraduação em Ciências Ambientais (UESB), Diretor do Sistema UESB de Rádio e Televisão Educativa (SURTE) e Assessor Geral de Comunicação da UESB, Universidade Estadual do Sudoeste da Bahia (UESB). E-mail: rubensjsampaio@uesb.edu.br

${ }^{3}$ Doutor em Biologia Vegetal, pela Universidade Federal de Pernambuco (2008) e Universität Kaiserslautern Alemanha, Pós-Doutor pela Universidade Estadual de Campinas (Unicamp) e Universidade Estadual do Sudoeste da Bahia (UESB). Professor titular da Universidade Estadual do Sudoeste da Bahia (UESB), Departamento de Ciências Exatas e Naturais (DCEN), Itapetinga-BA. E-mail: paulosavio@uesb.edu.br
} 
Este artículo presenta una retrospectiva de la historia ambiental, desde la aparición del hombre y sus primeras intervenciones significativas en la naturaleza, hasta su posición como una fuerza de igual magnitud que las fuerzas naturales, con la posibilidad de inaugurar una nueva época geológica, llamada Antropoceno. En secuencia, describimos las conferencias ambientales internacionales y sus efectos en el sistema legal nacional. Se hace una reflexión sobre el escenario político brasileño, buscando desentrañar cómo o cuánto los recientes cambios en la estructura del Ministerio del Medio Ambiente comprometen la educación ambiental y, si se vislumbra el retroceso del tema, cómo y cuántos años de evolución e impregnación de un concepto se vieron comprometidos. Investiga si existe una correspondencia entre el discurso internacional sobre educación ambiental y el escenario de la patria, a través de su inserción prominente en la legislación y en el presupuesto para la ejecución de sus programas y proyectos.

Palabras clave: Antropoceno. Holoceno. Legislación Ambiental. Medio Ambiente. Política Pública.

\section{Introdução}

Para compreender a educação ambiental, sua conceituação e tendências, é preciso situá-la no tempo e no espaço. Majoritariamente, aponta-se a Conferência das Nações Unidas para o Meio Ambiente Humano realizada em Estocolmo, em 1972, como o marco da educação ambiental. Todavia, muitos foram os acontecimentos que reforçaram sua indicação como ferramenta para amenizar a crise ambiental. De igual forma, trazida de seu contexto de origem para o contexto pátrio, outro panorama precisa ser tecido, para a verificação da aceitação das diretrizes internacionais pela legislação, órgãos e educadores ambientais nacionais.

Com essa intencionalidade, este trabalho traz uma retrospectiva de acontecimentos que marcaram a história ambiental. Acredita-se que a análise dos movimentos históricos auxilie na compreensão do cenário de surgimento da educação ambiental e na reflexão quanto sua validade e permanência para enfrentar quadro de condições planetárias intensamente modificadas pelo ser humano.

Além disso, dentro da máxima de pensar globalmente e agir localmente, exsurge a necessidade de conhecer o cenário ambiental, legislativo e político pátrio em que se insere a educação ambiental. Sobretudo, quando mudanças no cenário político brasileiro podem comprometer a educação ambiental. É importante refletir se recentes estruturações no Ministério do Meio Ambiente significam retrocesso do tema e, em caso positivo, como e quantos anos de evolução e impregnação de um conceito foram comprometidos. Da mesma forma, investigar se há correspondência entre o discurso internacional sobre a educação ambiental e o cenário pátrio, mediante sua inserção destacada na legislação e garantia orçamentária para a execução de seus programas e projetos.

O trabalho foi dividido em três partes. No primeiro bloco, descreve-se o quadro de intervenção humana sobre o meio ambiente, desde o Holoceno até a nova época geológica, denominada Antropoceno, contemplando, portanto, cerca de onze mil anos de história. No segundo bloco, são narradas as providências adotadas pelos países, sob a coordenação da Organização das Nações Unidas, para a reversão da crise ambiental, dentre elas a discussão das questões em cúpulas internacionais e a indicação da educação ambiental como ferramenta. Por fim, no terceiro e último bloco, são analisados os efeitos das conferências internacionais sobre o conjunto legislativo pátrio, em especial, quanto ao percurso da educação ambiental nos diferentes diplomas legislativos e na estrutura administrativa federal, com análise de recentes mudanças implementadas nos órgãos responsáveis por sua gestão e execução.

\section{Da Pré-história aos dias atuais, a jornada humana sobre a Terra}


A história biológica indica que o aparecimento da vida na Terra pode ser estimado em 3,5 bilhões de anos, enquanto a história geológica, em 4,5 bilhões (PÁDUA, 2010). Em termos de escala geológica, o planeta atravessou o éon Fanerozoico, a era Cenozoica, o período Quaternário e época Holoceno (BRANCO, 2016). Também conhecido como Idade do Gelo, e iniciado com o fim da última era glacial principal (VIOLA; BASSO, 2016; RODRIGUES, 2017), foi durante o Holoceno que ocorreu o aparecimento do Homo sapiens (BRANCO, 2016; ROHDE, 2005).

Sendo indispensável proceder ao recorte temporal de análise, opta-se por partir da préhistória para situar a exploração e apropriação de recursos naturais pelo homem. Nesse contexto temporal, pode-se indicar que o uso de cavernas, a caça e a coleta, mencionados como ocorrências da pré-história no período Paleolítico (SOFFIATI, 2016), eram modos de aproveitamento de elementos do meio ambiente natural para a vivência do ser humano. Caracterizaram a fase dos caçadores-coletores nômades. Porém, com seu domínio sobre o fogo, com o qual o ser humano passou a dispor de nova fonte de energia (REDIN et al., 2011), modificações mais significativas puderam ser vislumbradas em sua vida e na paisagem. A partir desse marco, o ser humano modificou sua dieta (PYNE, 2001; STEFFEN; CRUTZEN; McNEILL, 2007). Passou ao consumo de alimentos cozidos, alterando o modo de preparo de vegetais e proteína animal (NAVARRO, 2006), bem como utilizou o fogo em florestas, com o objetivo de abertura de clareiras para agricultura (STEFFEN; CRUTZEN; McNEILL, 2007). A manipulação controlada do fogo pelo homem também proporcionou o desenvolvimento de metalurgia, promovendo a construção de artefatos e materiais bélicos (ASSUNÇÃO; MALHEIROS, 2014; STEFFEN; CRUTZEN; McNEILL, 2007) incrementados pela fusão de matérias-primas (REDIN et al., 2011) obtidas a partir de elementos da natureza.

Aquele momento histórico foi denominado Revolução Agrícola (TILIO NETO, 2010). Trouxe o sedentarismo durante o Neolítico e ficou caracterizado pelo conhecimento e manipulação de plantas, domesticação de animais, aumento da produtividade, maior segurança alimentar, crescimento populacional e fixação permanente das populações em um determinado território, bem como predomínio de queima de madeira como combustível. Apesar da influência antrópica sobre o meio ambiente, o homem rivalizava, mas não superava as forças da natureza (STEFFEN; CRUTZEN; McNEILL, 2007).

O cenário ambiental foi intensamente modificado, por ação humana, a partir da Revolução Industrial e guerras mundiais. Steffen, Crutzen e McNeill (2007) ressaltam a industrialização como transição importante tanto para humanidade como para a história da própria Terra. Isto deu-se em decorrência do uso de carvão e, mais adiante, de petróleo e gás, todos combustíveis fósseis, evoluindo-se para uma sociedade altamente energizada, embora com diferente distribuição e padrões de consumo (TILIO NETO, 2010). Para o ecólogo Stephen Boyden (apud GÓMEZ GARCÍA; MANSERGAS LÓPEZ, 2010) essa época da história ambiental inaugurou a terceira fase ecológica, a que denominou de industrial ou "sociedade de alta energia" (s.p).

Steffen, Crutzen e Mcneill (2007) asseveram, ainda, que decorrente de mudanças políticas e econômicas, o mundo conheceu aceleração de crescimento, com urbanização e aumento do contingente populacional. Por mais paradoxal que possa parecer, para eles, a grande aceleração ocorreu após a I Guerra Mundial, a Grande Depressão e a II Guerra Mundial, na metade do século XX (CARRINGTON, 2016). A explicação repousa na expansão orçamentária, a financiar ciência e modelo tecnológico predatório, que se valiam de intensa e despreocupada exploração dos recursos naturais para obter sua matriz energética (LIMA, 2011). O período também ficou conhecido como anos dourados, de melhoria 
econômica em países capitalistas industrializados, socialistas e alguns integrantes do bloco dos países em desenvolvimento, como o Brasil (LIMA, 2011).

Tilio Neto (2010) resume o cenário e as consequências dessa fase:

\begin{abstract}
A Revolução Industrial culminou com o rápido avanço tecnológico do século XX. Ela resultou do domínio do homem sobre os combustíveis fósseis, do consequente aumento da produtividade, do advento da produção em massa. Essa revolução também levou à exploração em larga escala de muitos recursos naturais não renováveis, o que ocasionou uma grande abundância material. Embora essa abundância tenha sido distribuída de forma desigual (tanto dentro das sociedades quanto entre elas), alguns setores e algumas regiões foram beneficiados. Isso ajudou a potencializar a explosão populacional e o aumento do consumo mundial.
\end{abstract}

A partir de então, vozes passaram a anunciar o esgotamento e o colapso dos recursos naturais (ORTEGA, 2016). Preocupava o descompasso entre a velocidade da exploração pelo homem e a reposição natural. Afinal, como sustenta Tilio Neto (2010), o tempo de produção de bens na indústria é muito menor que o tempo ecológico de sua produção. Preocupavam, igualmente, a capacidade ou limite de suporte dos ecossistemas naturais (PHILIPPI JR.; MALHEIROS, 2014; LOURENÇO, 2018), também denominadas "limitações biofísicas do ambiente" (ALMEIDA JR., 2000, p.12). Em sua análise sobre o período, Rodrigues et al. (2019) apontam a redução da quantidade de recursos naturais e deterioração de sua qualidade. Tal cenário levava a questionar como proceder e encontrar substituições efetivas para recursos naturais não renováveis que estavam sendo exauridos.

Diante do agravamento dos impactos causados pela ação humana sobre o meio ambiente, a partir do século XVIII, pesquisadores contemporâneos, em análise retrospectiva, começaram a apontar para o surgimento de uma nova época geológica, o Antropoceno, em sucessão ao Holoceno. Embora nem todos aceitassem tal transição, por não se convencerem da suficiência da força do homem para alterar a escala temporal geológica (LINO, 2016), ou pela falta de expressão da mudança no cenário em determinados locais (IVAR, 2016) entendendo não ser correto atribuir a responsabilidade a toda humanidade, de forma unificada (MARQUESAN et al., 2018), a questão passou a ser discutida, não tanto quanto a ocorrência do Antropoceno, mas muito mais sobre quando teria começado.

Cabe esclarecer que "dentro da tabela cronoestratigráfica internacional, que fatia a escala temporal geológica em éons, eras, períodos, épocas e idades" (RODRIGUES, 2017, p. 20), os pesquisadores divergiam do termo final do Holoceno e inicial para o Antropoceno. Alguns indicavam a Revolução Agrícola, há dez mil anos, por sua capacidade de alteração locacional de sedimentos; outros, o final do século XVIII, com a Revolução Industrial, pelo uso de combustíveis fósseis. Por fim, um terceiro grupo de pesquisadores tomou como referência inicial do Antropoceno o pós-guerra, na década de 1950, que desencadeou a fase denominada "Grande Aceleração" (RODRIGUES, 2017, p.4), com lançamento de novos produtos e geração de resíduos a serem descartados.

Dentre os que entendem que o Antropoceno começou na Revolução Industrial, estão as pesquisadoras Luz e Marcal (2016) e Paul Crutzen (2002). As pesquisadoras definiram o Antropoceno "como uma nova época geológica, que começou durante a Revolução Industrial e levou a mudanças na natureza dos depósitos, no relevo e na composição da atmosfera" (LUZ; MARCAL, 2016, p. 158). Já Paul Crutzen (2002), cientista que popularizou a palavra Antropoceno (CARRINGTON, 2016), é mais específico ainda, ao sustentar que o início dessa época coincide com o aperfeiçoamento ou refinamento (STEFFEN; CRUTZEN; McNEILL, 2007) do motor a vapor por James Watt, entre 1770 e 1780, equipamento que inaugurou novo período na Revolução Industrial. 
Apesar das discussões e do tempo necessário para que o novo vocabulário se fixe, as discussões não são improfícuas. O termo Holoceno, para exemplificar, levou mais de cinquenta anos para ser aceito (MARQUESAN et al., 2018), sendo definido em 2008 (IVAR, 2016). Para Marquesan et al. (2018, p. 4), o mérito desse debate é a "abertura de uma nova arena para a denúncia da questão ecológica no campo científico, além de fomento à crítica à crença modernista de que ciência e tecnologia podem solucionar os problemas da humanidade".

Durante a $35^{\mathrm{a}}$ edição do Congresso Geológico Internacional, em Cape Town, África do Sul, em 2016, prevalecia como termo inicial do Antropoceno a década de 1950 (MEDIA...,2016), devido à longa série de testes nucleares pelas grandes potências, com dispersão de material radioativo (AÇÃO..., 2016), que foi identificado em camadas de gelo formadas naquela década (MARQUESAN et al., 2018). Entretanto, os debates não foram encerrados, postergando-se para novo encontro (VEIGA, 2017), ainda mais que os pesquisadores continuaram divergindo quanto ao local em que a nova época teria iniciado (CARRINGTON, 2016).

\section{A resposta ao cenário de degradação ao meio ambiente: a evocação à educação ambiental em conferências internacionais}

Nesse cenário de alertas, chefes de estado de cento e treze países reuniram-se na I Conferência das Nações Unidas para o Meio Ambiente Humano, em Estocolmo, no ano de 1972 (DA CONFERÊNCIA..., [2012?]), para debates sobre meio ambiente, com enfoque também na educação ambiental. A Conferência de Estocolmo inaugurou a discussão de uma agenda comum aos países signatários frente aos problemas ambientais e o surgimento do direito ambiental internacional (DA CONFERÊNCIA..., [2012?]). Por essa razão, é referida por Lima (2011, s.p) como "o primeiro marco internacional de constituição de um novo campo social", que associou educação, sociedade e meio ambiente e que delegou à educação ambiental papel estratégico frente a crise ambiental.

A partir de Estocolmo, muitos foram os encontros governamentais e não governamentais, tanto de caráter internacional como nacional, para discutir conceitos, princípios, diretrizes e outros temas relacionados à educação ambiental, creditando-a como instrumento para reversão da crise ambiental (SAISSE; LOUREIRO, [2013?]). Tantos foram que, segundo Reigota (1994), "a educação ambiental tem uma história quase oficial, que a relaciona com conferências mundiais e com os movimentos sociais em todo o mundo".

No ano de 1975, por exemplo, atendendo às recomendações da Conferência de Estocolmo para construção de referencial, a Organização das Nações Unidas para a Educação, a Ciência e a Cultura (UNESCO) promoveu o Encontro Internacional em Educação Ambiental, em Belgrado, na antiga Iugoslávia (CUMPLIDO; PRIETO, 2009). Durante esse evento, foi criado o Programa Internacional de Educação Ambiental (PIEA), "que tem sua importância no sentido de dar organicidade e visibilidade aos trabalhos do campo da educação ambiental" (BIASOLI, 2018, s.p). Igualmente, foi elaborada a Carta de Belgrado, definindo princípios, diretrizes e objetivos para a educação ambiental (REIGOTA, 1994; GÓMEZ GARCÍA; MANSERGAS-LÓPEZ, 2010).

Iniciaram-se, então, as conferências sobre educação ambiental, da qual Tbilisi (Geórgia), em 1977, ao sediar a Primeira Conferência Intergovernamental de Educação Ambiental (GUPTA, 2010), foi considerada como palco marcante, o "principal marco definidor oficial da educação ambiental" (LIMA, 2011, s.p). Outros encontros em âmbito internacional foram realizados, dentre eles destacam-se Encontro Regional de Educação Ambiental para América Latina, em San José, Costa Rica, em 1979; o Congresso Internacional sobre Educação e Formação Relativas ao Meio Ambiente, em Moscou, em 1987 
a Conferência Internacional sobre Meio Ambiente e Sociedade: Educação e Consciência Pública para a Sustentabilidade (BRASIL, [2003?]; LIMA, 2011) em Thessaloniki, na Grécia, no ano de 1997.

Em paralelo às específicas conferências de educação ambiental, a Organização das Nações Unidas promoveu outros encontros internacionais para discussão da situação do meio ambiente. Em que pese serem criticados pela fragilidade de seus compromissos (CARIDE; MEIRA, 2001; GÓMEZ GARCÍA; MANSERGAS-LÓPEZ, 2010) e serem apontados como ziguezagueantes (SCHIMIDT; NAVE; GUERRA, 2010), por nem sempre avançarem nas deliberações, o fato de manterem a Educação Ambiental na pauta de discussões internacionais já tem sua importância. Depois de Estocolmo, destacam-se, segundo a Organização das Nações Unidas no Brasil (ONU, 2017), as seguintes:

- Eco-92 ou Rio-92 (United Nations Conference on Environment and Development UNCED-, Earth Summit), realizada no Rio de Janeiro, Brasil, em junho de 1992, reconhecida pela própria Organização das Nações Unidas - ONU (UNITED..., [1992?]) como uma das maiores conferências que realizou. Também conhecida como Cimeira da Terra ou Cúpula da Terra (SOUSA; CARMO; ROCHA, 2013), foi o palco de publicação de documentos como a Agenda 21, Carta da Terra, Convenção sobre Diversidade Biológica, Convenção do Clima, Declaração do Rio sobre Meio Ambiente e Desenvolvimento, Convenção sobre Mudança do Clima, Princípios para a Administração Sustentável das Florestas (BRASIL, 2012).

- Rio+10 (World Summit on Sustainable Development - WSSD-, Johannesburg Summit), realizada em Joanesburgo, na África do Sul, em 2002. Além do nome oficial Conferência Mundial sobre Desenvolvimento Sustentável, também pode ser chamada de Cimeira de Joanesburgo, Rio + 10, Cúpula da Terra II (SOUSA; CARMO; ROCHA, 2013).

- Rio+20 (United Nations Conference on Sustainable Development), novamente realizada no Rio de Janeiro, em junho de 2012.

- Cúpula de Desenvolvimento Sustentável (United Nations Sustainable Development Summit 2015), ocorreu em Nova York, na sede da ONU, em 2015. Nesse encontro, avaliaram-se os Objetivos do Milênio (ODM) e acertou-se o cumprimento de uma agenda com novos Objetivos de Desenvolvimento Sustentável (ODS), a serem revisados em 2030 (DAS CONFERÊNCIAS, 2017).

A ilustração abaixo (Figura 1) mostra a intersecção das conferências internacionais sobre o meio ambiente realizadas pela Organização das Nações Unidas (ONU), a partir de Estocolmo, sintetizando os principais movimentos sobre meio ambiente e educação ambiental: 


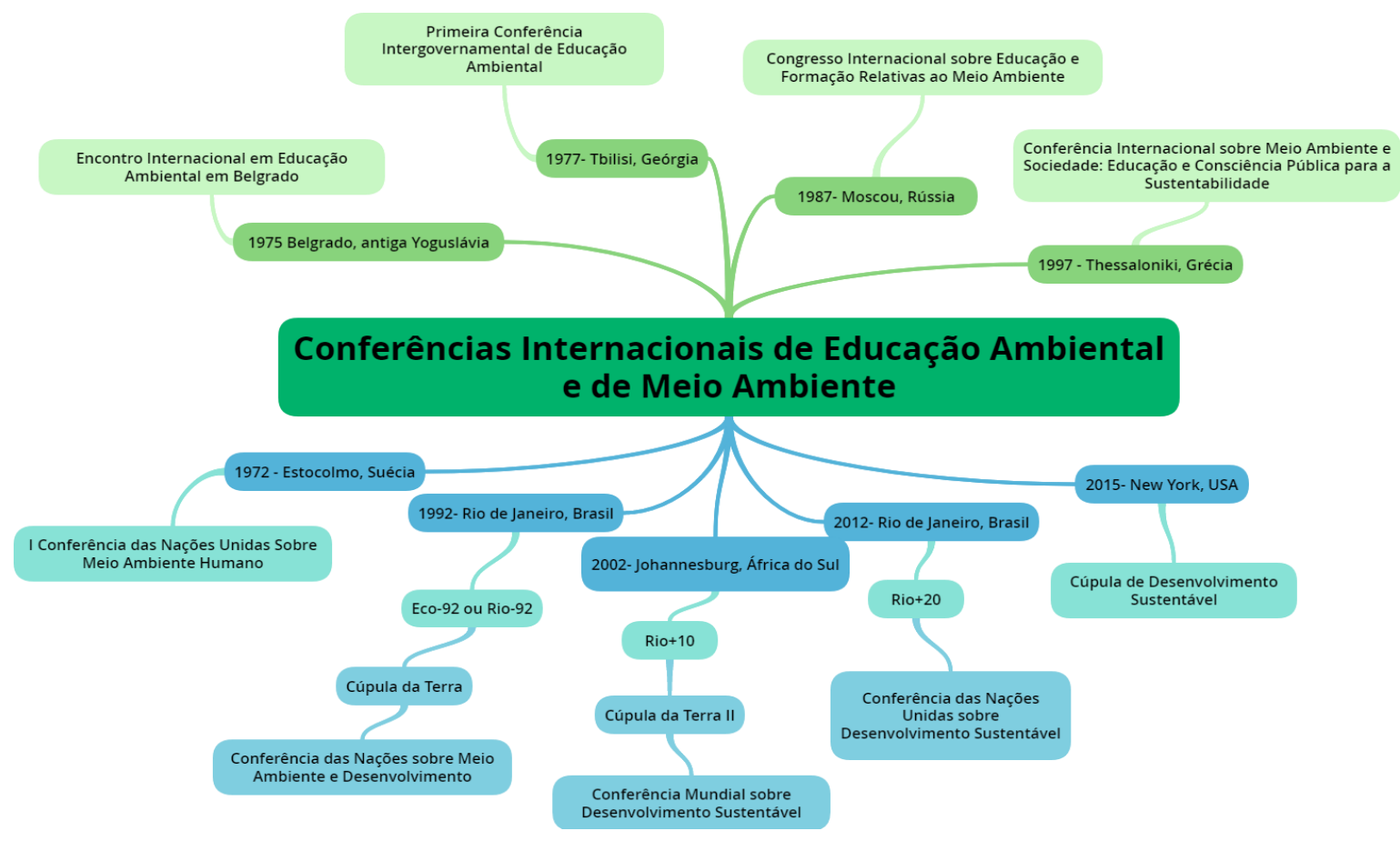

Figura 1 - Principais Conferências Internacionais de Educação Ambiental e de Meio Ambiente Fonte: autoria própria

\section{A internalização das conferências internacionais de meio ambiente pelo Brasil: a adoção da educação ambiental no ordenamento jurídico pátrio}

Embora o Brasil tenha participado de todas as conferências internacionais de meio ambiente e se comprometido com a implantação da educação ambiental, para Machado (2014), a institucionalização desse campo no cenário nacional ocorreu com o advento da Lei Federal n. 6.938, de 31 de agosto de 1981 (BRASIL, 1981), que trata da Política Nacional do Meio Ambiente. Para a autora, foi por meio desse diploma legal que o país internalizou as influências da Conferência de Tbilisi em seu ordenamento jurídico, podendo ser apontado como "marco legal federal da institucionalização da EA [educação ambiental] brasileira" (MACHADO, 2014, p. 50).

Machado (2014) chama a atenção, ainda, para o fato de que a educação ambiental, no Brasil, começou pela área ambiental e que, somente anos depois, ocorreu a normatização na área da educação, consubstanciada pelo artigo 36, inciso I, da Lei Federal n. 9.394, de 20 de dezembro de 1996 (BRASIL, 1996), conhecida como Lei de Diretrizes e Bases da Educação, quando a citação expressa do termo ocorreu no cenário educacional. Esse histórico da educação ambiental com impulso e herança maior a partir do campo ambiental para, depois, estender-se ao campo educacional, também é referido na obra de Lima (2011).

Em 1988, o Brasil elevou a Educação Ambiental ao cenário constitucional, estabelecendo sua obrigatoriedade no artigo $225, \S 1^{\circ}$, inciso VI, da Carta Magna (BRASIL, 1988). Posteriormente, assinou importantes documentos internacionais, nos quais reforçava seu compromisso pela educação ambiental, como a Carta Brasileira para a Educação Ambiental (BRASIL, 2018) e Agenda 21, com a educação ambiental contemplada especialmente no Capítulo 36 (BIASOLI, 2018). Outro documento de referência, ainda que sua autoria repouse na sociedade civil internacional, incluindo "educadores/as do mundo inteiro" (BIASOLI, 2018, s.p), foi o Tratado sobre Educação Ambiental para Sociedades 
Sustentáveis, elaborado durante a Eco-92, no Rio de Janeiro, mas fora da pauta oficial (BRASIL, 2014).

Em análise da institucionalização da educação ambiental no Brasil, Lima (2011) aponta que foi constituída sobre três pilares. O primeiro deles seria o Ministério do Meio Ambiente (MMA), com seu Departamento de Educação Ambiental (DEA). O segundo, seria o Ministério da Educação, por meio da Coordenação Geral de Educação Ambiental (CGEA). O terceiro e último pilar seria o Instituto Brasileiro do Meio Ambiente e dos Recursos Naturais Renováveis (IBAMA), criado em 1989 (BRASIL, 1989), com sua Coordenadoria Geral de Educação Ambiental (CGeam) e seus Núcleos de Educação Ambiental (NEAs), vinculados às Superintendências Regionais. Tinham diferentes públicos-alvo, posto que o Departamento de Educação Ambiental (DEA/MMA) e a Coordenadoria Geral de Educação Ambiental (CGEam/IBAMA) voltavam-se para a educação não formal, o Ministério da Educação, por meio da Coordenação Geral de Educação Ambiental (CGEA), atendia a instituições de educação, em todos os níveis de ensino (BRASIL, 2008).

Esse "tripé nucleador da geração de políticas públicas" (LIMA, 2011, s.p) fora construído com lentidão, se tomada como referência a data da primeira Conferência Internacional de Meio Ambiente, ocorrida em 1972. Somente em 21 de julho de 2003 (BIASOLI, 2018), em reunião conjunta do Ministério do Meio Ambiente (MMA) e do Ministério da Educação (MEC), para formalização de um Termo de Cooperação Técnica para a realização da Conferência Infantojuvenil pelo Meio Ambiente, é que a constituição do órgão gestor da Política Nacional de Educação Ambiental consolidou-se, mediante a articulação e trabalho comum dos dois ministérios, representados, respectivamente, pelo Departamento de Educação Ambiental (DEA) e pela Coordenadoria Geral de Educação Ambiental (CGEA) (BRASIL, 2014).

Não obstante, desde o ano de 2007 esse tripé passou a ser, peça por peça, desmontado. Através da Medida Provisória n. 366, de 26 de abril de 2007 (BRASIL, 2007a), sob o argumento de restruturação, mas também interpretado como revide pela rejeição ao licenciamento ambiental de duas grandes usinas hidrelétricas no rio Madeira, em Rondônia, obras no interesse do modelo de crescimento desenvolvimentista do governo federal (SAISSE; LOUREIRO [2013?]; LOUREIRO; SAISSE; CUNHA, 2013; LOUREIRO; SAISSE, 2014), ocorreu a cisão do Instituto Brasileiro do Meio Ambiente e dos Recursos Naturais Renováveis (IBAMA).

De seu desmembramento, surgiu o Instituto Chico Mendes de Conservação da Biodiversidade (ICMBio). A Coordenadoria Geral de Educação Ambiental (CGEam) do Instituto Brasileiro do Meio Ambiente e dos Recursos Naturais Renováveis (IBAMA) foi apagada (SAISSE, 2013) e não havia previsão de unidade organizacional para a educação ambiental na nova autarquia (BRASIL, 2007; LOUREIRO; SAISSE, 2014). Houve protestos de entidades ambientalistas e greve dos servidores do Instituto Brasileiro do Meio Ambiente e dos Recursos Naturais Renováveis - IBAMA (BLOG IBAMA, 2007a; ASCEMA, 2007; LOUREIRO; SAISSE, 2014;), não só pelo fim desse setor de educação ambiental, mas pela fragmentação e enfraquecimento da autarquia (PARO, 2007).

O processo foi denominado por Saisse e Loureiro ([2013?], p.30) como "desinstitucionalização da educação ambiental no órgão executor da gestão ambiental pública federal". Criticou-se o uso de Medida Provisória, por remeter ao decreto-lei dos anos da ditadura. Outra crítica apontou a falta de discussão com a sociedade (BLOG IBAMA, 2007a; ASSOCIAÇÃO SERVIDORES IBAMA, 2007b) e a questionabilidade do requisito da urgência que deveria amparar a medida provisória (PINTO, 2007), objeto de ação direta de inconstitucionalidade (ADI) n. 4.029 perante o Supremo Tribunal Federal (DECISÃO...,2012; STF...,2012). 
A Medida Provisória n. 366, de 26 de abril de 2007 (BRASIL, 2007a), todavia, foi convertida na Lei n. 11.516, de 28 de agosto de 2007 (BRASIL, 2007b). O texto legal amenizou parcialmente a situação, já que previu, no artigo $1^{\circ}$, inciso III, a educação ambiental como uma das funções do Instituto Chico Mendes de Conservação da Biodiversidade (ICMBio), previsão que não constava do instrumento normativo original.

Cabe ressaltar que a educação ambiental no Instituto Chico Mendes de Conservação da Biodiversidade (ICMBio), pela própria finalidade dessa autarquia, não tem a amplitude da que era praticada pelo Instituto Brasileiro do Meio Ambiente e dos Recursos Naturais Renováveis (IBAMA). Destina-se a processos educativos associados à qualificação da participação social na gestão das Unidades de Conservação e para a promoção da biodiversidade (ICMBio, 2019a, 2019b, 2019c, 2019d), mantendo laços com as visitas e pesquisas nos locais sob a gestão do Instituto (BRASIL, 2020a; ICMbio, 2016). Atende atores sociais envolvidos com a gestão pública da biodiversidade, ou seja, os servidores da autarquia, conselho gestor, pessoas envolvidas ou atuantes em Unidades de Conservação e público externo (ICMBio, 2019c; LOUREIRO; SAISSE, 2014). Os locais de atuação são as unidades de conservação federais e seu entorno e os Centros Nacionais de Pesquisa e Conservação (BRASIL, 2020a; ICMBio, 2019a, 2019c). Assim sendo, a educação ambiental no Instituto Chico Mendes de Conservação da Biodiversidade (ICMBio) é praticada de modo restrito.

A educação ambiental no Ministério do Meio Ambiente também sofreu revezes. Por meio do Decreto n. 6.101, de 26 de abril de 2007 (BRASIL, 2007c), a Diretoria de Educação Ambiental foi rebaixada para Departamento de Educação Ambiental, subordinado à Secretaria de Articulação Institucional e Cidadania Ambiental.

Outrossim, recentes modificações na organização administrativa federal prosseguiram com a desestruturação do tripé da educação ambiental. O Departamento de Educação Ambiental do Ministério de Meio Ambiente foi extinto, no início de 2019, pela Medida Provisória n. 870, de $1^{\circ}$ de janeiro de 2019 (BRASIL, 2019d), convertida na Lei n. 13.884, de 18 de junho de 2019 (BRASIL, 2019c). Pelo organograma decorrente desse diploma legal, a educação ambiental passou para a pasta da Secretaria de Ecoturismo, sob a responsabilidade dos Departamentos de Comunicação e de Fomento e Projetos, como pode ser visto nos artigos 30 e 31 do Decreto n. 9.672, de 2 de janeiro 2019 (BRASIL, 2019b), a seguir transcritos:

\footnotetext{
Art. 30. Ao Departamento de Comunicação compete:

(...)

II - apoiar a Secretaria de Ecoturismo na elaboração de peças de educação ambiental, ecoturismo e atividades econômicas voltadas ao Meio Ambiente; e (...) Art. 31. Ao Departamento de Fomento e Projetos compete:

I - Realizar e planejar projetos e ações de fomento à Ecoeconomia, Educação Ambiental e Ecoturismo e nos diversos segmentos e entes federativos, bem como nos meios influenciadores;

(...)

III - acompanhar e monitorar ações, iniciativas, estratégias, programas e projetos de Ecoeconomia, Educação Ambiental e Ecoturismo; e

(...) (BRASIL, 2019b, p. 29, grifos dos autores)
}

Em relação ao Ministério da Educação, com a reestruturação operada pelo artigo 12 do Decreto n. 9.665, de 2 de janeiro de 2019 (BRASIL, 2019a), a educação ambiental passou a integrar as atribuições da Diretoria de Políticas e Regulação da Educação Básica, subordinada à Secretaria de Educação Básica. Em 2018, incumbia à Coordenação Geral de Educação Ambiental (CGEA) vinculada à Diretoria de Educação Integral, Direitos Humanos e Cidadania da Secretaria de Educação Continuada, Alfabetização e Diversidade do Ministério da Educação (Secad/MEC). 
Importante transcrever a norma citada (BRASIL, 2019a):

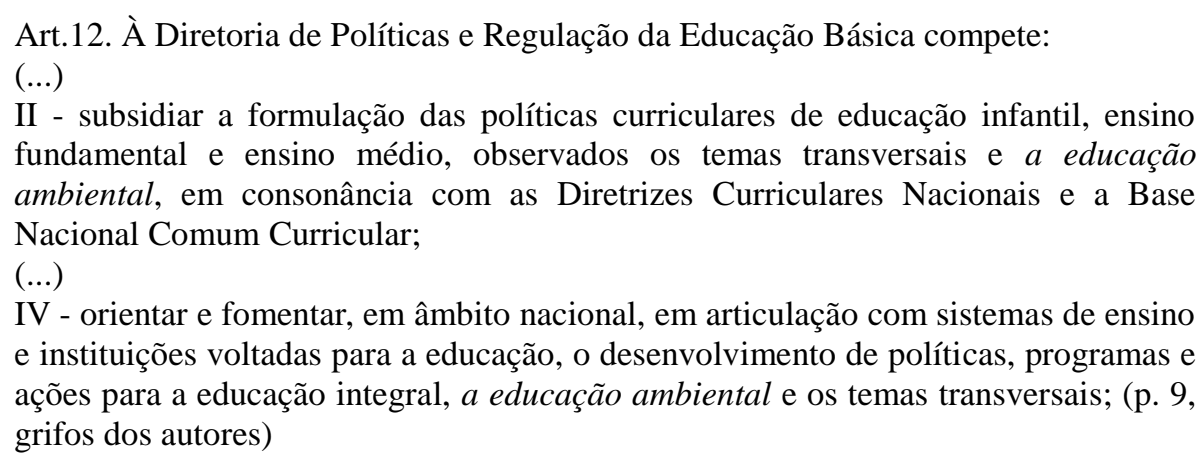

A modificação preocupou e gerou manifestação da comunidade acadêmica brasileira ligada ao campo da educação ambiental (EDUCADORES..., 2019, NASSIF, 2019; OBSERVARE, 2019). Um dos motivos foi a alocação da educação ambiental na Secretaria de Educação Básica, no âmbito do Ministério da Educação e, ainda por cima, feita por meio de decreto, que restringe o debate público e o acompanhamento pelo Parlamento (BOURSCHEIT, 2019). Como sustentou a Rede Brasileira de Educação Ambiental - REBEA, em rebate a tais decretos, a educação ambiental deve ser ministrada em todos os níveis de ensino. Posicioná-la administrativamente em órgão voltado para educação básica, desconsidera o preceito legal que determina que a Educação Ambiental deve ocorrer desde a educação infantil até o ensino superior (REBEA, 2019a).

Do mesmo modo, houve mobilização contra o reducionismo da importância da educação ambiental no Ministério de Meio Ambiente, pela sua colocação na Secretaria de Ecoturismo (CDHPF, 2019). Comissões Interinstitucionais de Educação Ambiental de vinte unidades federativas do Brasil (CIEAS) ofertaram um manifesto contrário às medidas trazidas pelo Decreto n. 9.672, de 2 de janeiro de 2019 (BRASIL, 2019b). Propuseram a redenominação da Secretaria de Ecoturismo para Secretaria de Educação Ambiental e Ecoturismo, modificação que resolveria, ao menos, a questão hierárquica entre as duas temáticas.

Embora os dois decretos já tenham sido objeto de revogação, as críticas eram pertinentes. De fato, pela interpretação do então vigente Decreto n. 9.672, de 2 de janeiro de 2019 (BRASIL, 2019b), que reestruturou o Ministério do Meio Ambiente, podia-se identificar a redução da importância da educação ambiental como atribuição desse órgão. A maneira como fora posicionada na norma, com sua previsão em incisos, implicava a subsunção à pasta de Ecoturismo, que lhe era orientador e superior em importância, por estar no caput do artigo.

Com a alteração efetuada pelo Decreto n. 10.455, de 11 de agosto de 2020 (BRASIL, 2020b), a coordenação, o acompanhamento e a avaliação da implementação da Política Nacional de Educação Ambiental no âmbito do Ministério do Meio Ambiente foram atribuídos à Secretaria da Biodiversidade. Houve a (re)criação de departamento específico para cuidar da educação ambiental, batizado com o nome de Departamento de Educação e Cidadania Ambiental. A Secretaria de Ecoturismo, a seu turno, foi extinta nesse Ministério (FARIAS, 2020).

Todavia, ainda que com essas mudanças, continua-se a incidir em duas falhas. A primeira, pelo desatendimento da Política Nacional de Educação Ambiental e de seu regulamento, constituído pelo Decreto n. 4.281, de 25 de junho de 2002 (BRASIL, 2002). Por esse regulamento, a Educação Ambiental deveria pairar sobre, cobrir como um guarda-chuva todas as demais ações e atividades, ser concebida de forma estruturante e tratada como prioridade. Tanto que, em seu artigo $6^{\circ}$, inciso II, prevê as atividades de conservação da 
biodiversidade e de ecoturismo como um dos campos de educação ambiental, como pode ser depreendido da transcrição a seguir:

\begin{abstract}
Art.6. Para o cumprimento do estabelecido neste Decreto, deverão ser criados, mantidos e implementados, sem prejuízo de outras ações, programas de educação ambiental integrados:

(...)

II- às atividades de conservação da biodiversidade, de zoneamento ambiental, de licenciamento e revisão de atividades efetivas ou potencialmente poluidoras, de gerenciamento de resíduos, de gerenciamento costeiro, de gestão de recursos hídricos, de ordenamento de recursos pesqueiros, de manejo sustentável de recursos ambientais, de ecoturismo e melhoria de qualidade ambiental (BRASIL, 2002, p. 13, grifos dos autores)
\end{abstract}

Na vigência do Decreto n. 9.672, de 2 de janeiro de 2019 (BRASIL, 2019b), a educação ambiental era temática meramente pontual ou demanda específica da Secretaria do Ecoturismo. Atualmente, ainda que reconquistada a colocação da educação ambiental sob a coordenação de um departamento específico, prossegue sua dependência hierárquica e financeira ao órgão que lhe é superior, no caso, a Secretaria de Biodiversidade.

Por outro ângulo, indiretamente estabelece-se associação restritiva entre meio ambiente natural e educação ambiental, pela nomenclatura da Secretaria a que pertence. Todavia, é sabido que meio ambiente vai além da preocupação com a diversidade biológica, ainda que esta seja "a soma de todas as espécies de organismos, a variabilidade de genes, a diversidade de ecossistemas e as complexas interações ecológicas que existem entre elas" (PORTAL MÁRCIO AYRES, 2021, s.p). Abarca aspectos socioculturais, de proteção ao clima e diversas outras condições, leis, influências e interações de ordem física, química ou biológica que afetam a vida, em todas as suas formas (BRASIL, 1981), e que são ou deveriam ser tratadas por outras Secretarias do Ministério de Meio Ambiente.

Desse modo, a educação ambiental deveria integrar todas as áreas de atuação da pasta ministerial e, para isso, sua natureza jurídica deveria ser, no mínimo, de órgão específico singular, para aproveitar a linguagem trazida pelo Decreto n. 10.455, de 11 de agosto de 2020 (BRASIL, 2020b), com título de Secretaria. Como está prevista, com subordinação a Secretaria de Biodiversidade, terá dificuldade para atingir aos demais campos e permitir a transversalidade.

A mudança efetuada, todavia, já foi um avanço. Não foi difícil asseverar que a Secretaria de Ecoturismo do Ministério do Meio Ambiente não lograria efetuar a penetração da educação ambiental nas demais secretarias. Não tinha hierarquia sobre elas, para imporlhes o cumprimento da educação ambiental. Igualmente, também não era sua finalidade precípua desenvolver a educação ambiental em todos os campos previstos no artigo $6^{\circ}$, inciso II, do Decreto $\mathrm{n}^{\circ}$ 4.281, de 25 de junho de 2002 (BRASIL, 2002), por exemplo, no licenciamento ambiental. Acompanhe-se trecho do revogado Decreto n. 9.672, de 2 de janeiro de 2019 (BRASIL, 2019b):

Art. 28. À Secretaria de Ecoturismo compete:

I - apoiar a coordenação e definição de políticas públicas relacionadas à promoção geral de atividades, campanhas, eventos e articulações de conscientização ambiental, relacionamento e interação com influenciadores, relacionados ao ecoturismo;

II - apoiar as atividades de produção cultural ambiental, de ecoeconomia, de promoção e de comunicação ambiental, fomentando o relacionamento transversal com os demais ministérios, no âmbito de suas atribuições; $\mathrm{e}$ 
III - estabelecer o diálogo e a interação com o setor público e o setor privado, setores da educação, cultura, turismo, agricultura, esporte, infraestrutura e saúde (p. 29, grifos dos autores)

Como previsto no não mais vigente artigo 28 do Decreto $n^{\circ} 9.672$, de 2 de janeiro de 2019 (BRASIL, 2019b), as políticas públicas da pasta deveriam ser norteadas pela sua finalidade estrutural. Além disso, como o orçamento da Secretaria de Ecoturismo englobava todas as atividades da pasta, não havendo rubrica exclusiva para a educação ambiental, a redução de verbas para projetos e programas educativos mostrava-se certa. A educação ambiental do Ministério de Meio Ambiente compartilharia dos recursos humanos e financeiros destinados ao ecoturismo. Pelo regramento atual, Decreto 10.455, de 11 de agosto de 2020 (Brasil, 2020b), ainda que com melhorias em relação ao revogado, as mesmas dificuldades podem ser previstas, especialmente diante da inexistência de orçamento próprio para o Departamento da Educação e Cidadania Ambiental, o qual está atrelado ao da Secretaria de Biodiversidade.

Como segunda falha, quando vigente o Decreto $\mathrm{n}^{\circ}$ 9.672, de 2 de janeiro de 2019 (BRASIL, 2019b), percebia-se a finalidade privatista e econômica do posicionamento assumido, relativo à educação ambiental vinculada ao ecoturismo. Dentro de uma engenharia administrativa, revelava um modelo de gestão pública que focada nos negócios de mercado. Basta consultar aos artigos 30 e 31 do Decreto n. 9.672, de 2 de janeiro de 2019 (BRASIL, 2019b), anteriormente transcritos, quando previam como competência do Departamento de Comunicação o apoio à Secretaria de Ecoturismo na elaboração de peças de educação ambiental, ecoturismo e atividades economicas voltadas ao Meio Ambiente, ou ainda, a competência do Departamento de Fomento e Projetos para planejar, coordenar e executar ações, projetos e programas que fomentem as atividades geradoras de renda e emprego nos segmentos da economia de mercado ligados ao Meio Ambiente.

Ora, mantendo-se a educação ambiental ligada ao ecoturismo e às unidades de conservação, atendem-se a aspectos sociais de empregabilidade e empreendedorismo locais (SAISSE, 2013), contemplando aos interesses do mercado. Esse aspecto, em si, não é totalmente negativo, mas há de se perceber que, com tal medida, financia-se, indiretamente, com recursos públicos, negócios voltados para aventura e lazer, como serviços nos Parques Nacionais (SAISSE, 2013). Daí porque é crescente a indicação de atuação do poder público para fiscalização, poder de polícia e como regulador dos serviços de atendimento, lazer e infraestrutura nas unidades de conservação, deixando o custo e os riscos destes a quem detém a expertise na sua exploração (BRAGA, 2013; MELO; BARCELOS, 2018; RODRIGUES; GODOY, 2013; RODRIGUES; ABRÚCIO, 2019).

Por outro lado, mesmo que os contratos (lato senso) estabelecidos com a iniciativa privada para a administração das unidades de conservação possam prever a educação ambiental, é também responsabilidade do Estado sua execução. Como sustenta Braga (2013, p.118), "a iniciativa privada soma às competências do Poder Público, não as substitui", tampouco é "um salvo-conduto para o Estado deixar de cumprir suas responsabilidades".

Além disso, importa destacar que a questão maior continua a ser a limitação da educação ambiental não formal, dentro do Ministério de Meio Ambiente. Inicialmente, casada com o ecoturismo e atualmente, por força do Decreto $\mathrm{n}^{\circ} 10.455$, de 11 de agosto de 2020 (BRASIL, 2020b), com a biodiversidade, é tratada somente como um minus do que representa e do que vem sendo pregado internacionalmente. Como diz Saisse (2013), a lógica parece ser de esvaziar o que vinha sendo construído nas políticas públicas ambientais para buscar-se a viabilidade econômica.

Como visto, no âmbito federal fixou-se a educação ambiental (não formal) como incumbência do Instituto Chico Mendes de Conservação da Biodiversidade (ICMBio). No 
entanto, as possibilidades de um bom desempenho, por essa instituição, acabam comprometidas, por um lado, pela vinculação à Secretaria de Ecoturismo (BRASIL, 2019d), como ocorreu a partir de 2019 mediante a reforma administrativa no Ministério do Meio Ambiente, e, posteriormente, à Secretaria de Biodiversidade (BRASIL, 2020b), a qual a autarquia não integra (BRASIL, 2007b) e, por outro aspecto, devido aos novos diplomas legais e instrumentos jurídicos que permitem a concessão administrativa de parques nacionais e unidades de conservação para a iniciativa privada.

Percebe-se que a delegação anterior da educação ambiental ao Instituto Chico Mendes (ICMBio), retirando-a do Instituto Brasileiro do Meio Ambiente e dos Recursos Naturais Renováveis (IBAMA), não foi passo estanque. Como já indicado, foi atribuída ao primeiro para esvaziamento do próprio Instituto Brasileiro do Meio Ambiente e dos Recursos Naturais Renováveis (IBAMA), responsável anterior tanto pela educação ambiental não formal como pela execução do Sistema Nacional de Unidades de Conservação (SANTOS et al., 2020). Acentua-se, portanto, "o desmonte declarado das instituições de fiscalização", refletindo-se na perda de legitimidade daquele (SILVINO, 2020, s.p)

Com essas modificações, a cada passo, a educação ambiental perde sua organicidade institucional e é relegada a assunto periférico. Tanto que pouco ou sequer é mencionada nos novos decretos, que atualizaram as pastas federais da educação e do meio ambiente. Ao contrário, a educação ambiental não tem assento imediato e expresso nas atribuições do Ministério do Meio Ambiente, como pode ser visto do artigo $1^{\circ}$ do Anexo I do Decreto $\mathrm{n}^{\circ}$ 10.455, de 11 de agosto de 2020 (BRASIL, 2020b), que trata da estrutura regimental dessa pasta, a seguir transcrito:

\footnotetext{
Art. $1^{\circ} \mathrm{O}$ Ministério do Meio Ambiente, órgão da administração pública federal direta, tem como área de competência os seguintes assuntos:

I - política nacional do meio ambiente;

II - política de preservação, conservação e utilização sustentável de ecossistemas, biodiversidade e florestas;

III - estratégias, mecanismos e instrumentos econômicos e sociais para a melhoria da qualidade ambiental e o uso sustentável dos recursos naturais;

IV - políticas para a integração do meio ambiente e a produção econômica;

V - políticas e programas ambientais para a Amazônia;

VI - estratégias e instrumentos internacionais de promoção das políticas ambientais;

$\mathrm{e}$

VII - zoneamento ecológico econômico.
}

Idêntica situação é enfrentada no Ministério da Educação. Mesmo com as modificações legislativas operadas e reclamos das entidades educativas, alhures referidos, a educação ambiental não está claramente indicada nas atribuições da pasta. Nota-se que, no Anexo I do Decreto $\mathrm{n}^{\mathrm{o}}$ 10.195, de 30 de dezembro de 2019 (BRASIL, 2019e), em seu artigo $1^{\circ}$, no inciso III, o Ministério da Educação tem como competência tratar da educação em geral. Como integrantes dessa expressão, todavia, foram listados e especificados o ensino fundamental, o ensino médio, o ensino superior, a educação de jovens e adultos, a educação profissional, a educação especial e a educação a distância e excluído ensino militar. Nesse detalhamento, seria possível incluir a educação ambiental, para ceifar qualquer dúvida a respeito da competência do Ministério da Educação, ainda que partilhada a outra pasta.

Na mesma esteira de argumentação, se já era questionada a colocação da educação ambiental como atribuição somente da educação básica, com ausência de referência ao ensino superior, com a revogação do Decreto n. 9.665, de 2 de janeiro de 2019 (BRASIL, 2019a), a situação foi agravada. Como pode ser visto no Decreto n. 10.195, de 30 de dezembro de 2019 (BRASIL, 2019e), em seu artigo 12, inciso II, que corresponde ao artigo 12, inciso II, do revogado Decreto 9.665, de 2 de janeiro de 2019 (BRASIL, 2019a), o termo educação 
ambiental teve supressão expressa até mesmo das atribuições da educação básica. Somente por esforço interpretativo e de quem conhece o significado e os atributos de transversalidade desse conceito, é que pode ser entendido como responsabilidade da Secretaria de Educação Básica.

Importante efetuar-se a comparação dos artigos, para visualização da supressão do termo. No anterior Decreto 9.665, de 2 de janeiro de 2019 (BRASIL, 2019a), alvo de reclamações, a educação ambiental foi mencionada ao lado de assuntos transversais, como competência da Diretoria de Políticas e Regulação da Educação Básica:

Art. 12. À Diretoria de Políticas e Regulação da Educação Básica compete:

(...)

II - subsidiar a formulação das políticas curriculares de educação infantil, ensino fundamental e ensino médio, observados os temas transversais e a educação ambiental, em consonância com as Diretrizes Curriculares Nacionais e a Base Nacional Comum Curricular; (p. 9, grifos dos autores).

Atualmente, além da redenominação da Diretoria, o Decreto n. 10.195, de 30 de dezembro de 2019 (BRASIL, 2019e) suprime o termo educação ambiental do inciso II do artigo 12 de seu Anexo I, deixando-o implícito a temas transversais contemporâneos, como pode ser visto a seguir:

Art. 12. À Diretoria de Políticas e Diretrizes da Educação Básica compete:

(...)

II - subsidiar a formulação das políticas curriculares da educação básica, observados os temas contemporâneos transversais; (p. 4, grifos dos autores).

Acredita-se que as mudanças operadas a partir de 2019 refletirão na composição do órgão gestor da Política Nacional de Educação Ambiental. Devido a isso, as Comissões Interinstitucionais de Educação Ambiental de vinte unidades federativas do Brasil (CIEAS) também sugeriram a recriação do Departamento de Educação Ambiental (DEA), e a manutenção da Coordenação Geral de Educação Ambiental (CGEA) no âmbito do Ministério da Educação. Para essas Comissões Interinstitucionais (CIEAS), o órgão gestor da Política Nacional da Educação Ambiental deveria prosseguir com sua constituição mediante a integração dos Ministérios da Educação e do Meio Ambiente (REBEA, 2019b).

Resta o apego à Constituição Federal (BRASIL, 1988), à Lei n. 9.795, de 27 de abril de 1999 (BRASIL, 1999) e a sua regulamentação como garantia da educação ambiental, enquanto não forem modificadas. Todavia, com a retirada do principal executor federal Instituto Brasileiro do Meio Ambiente e dos Recursos Naturais Renováveis (IBAMA), a mira administrativa atual sobre o Instituto Chico Mendes de Conservação da Biodiversidade (ICMBio) (MACHADO, 2020; MESQUITA, 2020), associada à restrição orçamentária que se vislumbra, seja ela legal, contingencial ou provocada (VALPORTO, 2020), pode-se afirmar que houve uma quebra estrutural nos caminhos da educação ambiental, construídos desde 1972.

Por tal razão, é importante que os descaminhos legislativos, administrativos e de políticas públicas que se operam sejam acompanhados, de muito perto e com muita atenção, para que as intencionalidades ocultas sejam clarificadas e estampadas (SAISSE, 2013) e que o percurso histórico nacional da educação ambiental não seja de recuos e, sim, de avanços.

\section{Considerações Finais}


Foi apresentado o quadro histórico de intervenção humana no meio ambiente, igualando-se e até mesmo superando as forças da natureza, a ponto de implicar o reconhecimento de nova época geológica, o Antropoceno. O agravamento da deterioração ambiental em nível mundial (ORTEGA, 2016) impõe sejam aprofundados os estudos sobre metodologia e conceitos de educação ambiental, para sugerir e sustentar formas comprovadas de desempenho de seu papel de informação, formação e transformação ambiental, a partir da sensibilização e do favorecimento ao estabelecimento de novas relações, individuais e coletivas (CARIDE; MEIRA, 2001; GÓMEZ GARCÍA; MANSERGAS LÓPEZ, 2010), com o meio ambiente.

Para tanto, a continuidade das Conferências Internacionais de Meio Ambiente é importante, em seu papel de sensibilizar, alertar e comunicar a situação planetária. Esse efeito mínimo é obtido pela realização das cúpulas. Todavia, é preciso ir além, passando-se para efeitos mais concretos, de real comprometimento com a implementação das medidas mitigadoras da crise ambiental, com agenda clara e de efetivos compromissos.

Por outro lado, em relação ao cenário pátrio, as recentes estruturações nos Ministérios do Meio Ambiente e da Educação podem comprometer a educação ambiental, pela desarticulação do órgão gestor, previsto na Lei n. 9.795, de 27 de abril de 1999 (BRASIL, 1999), afetando a condução interministerial da Política Nacional de Educação Ambiental.

Igualmente, preocupa a subsidiariedade temática, orçamentária e institucional a que foi rebaixada, com redução do seu espectro espacial, sobretudo no que tange à educação ambiental não formal. Sua dependência ao orçamento e ao comando da Secretaria de Biodiversidade, por um lado, e sua execução transferida ao Instituto Chico Mendes de Conservação da Biodiversidade (ICMBio), nas áreas de sua atuação, significativamente diferenciadas e reduzidas em relação as outrora desempenhadas pelo Instituto Brasileiro do Meio Ambiente e dos Recursos Naturais Renováveis (IBAMA), podem vir a comprometer sua aplicação.

Percebe-se, destarte, a falta de correspondência entre o discurso internacional sobre a educação ambiental e o cenário pátrio, que, ao invés de destacá-la em todos os níveis de ensino e no âmbito não formal, a rebaixa na legislação administrativa e na operacionalização de órgãos federais, com consequentes afetações orçamentárias para a execução de seus programas e projetos. Desse modo, quanto ao cenário nacional, a mobilização da sociedade mostra-se essencial para a vigilância dos rumos das políticas públicas de educação ambiental e meio ambiente.

\section{Referências}

AÇÃO humana sobre planeta marca nova fase geológica, dizem cientistas. O Globo. Rio de Janeiro, 29 ago. 2016. Disponível em: <https://oglobo.globo.com/sociedade/ciencia/acao-humana-sobreplaneta-marca-nova-fase-geologica-dizem-cientistas-20010687>. Acesso em: 07 abr. 2019.

ALMEIDA JR. J.M.G. Um Novo Paradigma de Desenvolvimento Sustentável. Consultoria Legislativa da Câmara dos Deputados. Brasília: Câmara dos Deputados, 2000.

ALMEIDA, G.F. Estrutura Básica de um texto legal: artigo, parágrafo, inciso e alínea. São Paulo: Universidade de São Paulo, [2009?]. Disponível em: $<$ https://edisciplinas.usp.br/pluginfile.php/5569498/mod_resource/content/1/Estrutura\%20do\%20texto \%20legal.pdf>. Acesso em: 09 jul. 2021.

ASCEMA - Associação Nacional dos Servidores da Carreira de Especialista em Meio Ambiente. Institucional. Brasília: Ascema, 2007. Disponível em:

<http://www.ascemanacional.org.br/institucional/>. Acesso em: 15 jun. 2021. 
ASSOCIAÇÃO DE SERVIDORES DO IBAMA. Carta em defesa do Ibama: carta aberta aos parlamentares e ao povo brasileiro. Correio da Cidadania, São Caetano do Sul, (s.p), 04 de maio de 2007b. Disponível em:

$<\mathrm{http} / / / \mathrm{www}$. correiocidadania.com.br/index.php?option=com_content\&view=article\&id=263:cartaem-defesa-do-ibama\&catid=33:noticias-em-destaque>. Acesso em: 21 jun. 2019.

ASSUNÇÃO, J.V; MALHEIROS, T.F. Poluição Atmosférica. In: PHILIPPI JR. A., PELICIONI M.C.F. (Ed.). Educação ambiental e sustentabilidade. 2 ed. rev. e atual. Barueri: Manole, 2014. p 147-192.

BIASOLI, S. Fundamentos de educação ambiental para sustentabilidade. São Paulo: Senac, 2018. Ebook Kindle.

BLOG IBAMA. Carta aberta à Excelentíssima Senhora Ministra do Meio Ambiente Marina Silva. Brasília: IBAMA, 2007a. Disponível em: <https://ibama.wordpress.com/>. Acesso em: 21 jun. 2019.

BRAGA, A. S. Viabilização do Uso Público de Parques Nacionais e a Disponibilização por Particulares de Serviços de Apoio à Visitação. 2013. 172 f. Dissertação (Mestrado em Direito e Políticas Públicas) - Centro Universitário de Brasília-Uniceub, Brasília, 2013. Disponível em: <https://repositorio.uniceub.br/jspui/bitstream/235/5914/1/61000415.pdf>. Acesso em: 15 jun. 2021.

BOURSCHEIT, A. Desmonte de políticas ambientais é a marca dos 100 dias de governo Bolsonaro. Portal O Eco, 10 abr. 2019. Disponível em: <https://www.oeco.org.br/reportagens/desmonte-depoliticas-ambientais-e-a-marca-dos-100-dias-de-governo-bolsonaro/>. Acesso em: 10 jun. 2019.

BRANCO, P. M. Breve História da Terra. Portal CPRM Serviço Geológico do Brasil. Brasília- DF. 03 dez. 2016. Disponível em: <http://www.cprm.gov.br/publique/Redes-Institucionais/Rede-deBibliotecas---Rede-Ametista/Canal-Escola/Breve-Historia-da-Terra-1094.html>. Acesso em: 07 abr. 2019.

BRASIL, Lei 6.938, de 31 agosto de 1981. Dispõe sobre a Política Nacional do Meio Ambiente. Brasília: Casa Civil, 1981. Disponível em: 〈http://www.planalto.gov.br/ccivil_03/Leis/L6938.htm〉. Acesso em: 02 abr. 2019.

BRASIL. Constituição da República Federativa do Brasil. Promulgada em 05 de outubro de 1988. Brasília: Casa Civil, 1988. Disponível em:

<http://www.planalto.gov.br/ccivil_03/constituicao/constituicao.htm〉. Acesso em 18 out. 2019.

BRASIL. Lei 7.735, de 22 fevereiro de 1989. Dispõe sobre a extinção de órgão e de entidade autárquica, cria o Instituto Brasileiro do Meio Ambiente e dos Recursos Naturais Renováveis e dá outras providências. Brasília: Casa Civil, 1989. Disponível em: <http://www.planalto.gov.br/ccivil_03/LEIS/L7735.htm>. Acesso em: 21 jun. 2019.

BRASIL. Lei 9.394, de 20 dezembro de 1996. Estabelece as diretrizes e bases da educação nacional. Brasília: Casa Civil, 1996. Disponível em: 〈http://www.planalto.gov.br/ccivil_03/leis/19394.htm〉. Acesso em: 21 jun. 2019.

BRASIL. Lei 9.795, de 27 abril de 1999. Dispõe sobre a educação ambiental, institui a Política Nacional de Educação Ambiental e dá outras providências. Brasília: Casa Civil, 1999. Disponível em: <http://www.planalto.gov.br/CCIVil_03/LEIS/L9795.htm>. Acesso em: 28 ago. 2019.

BRASIL. Decreto n. 4.281, de 25 junho de 2002. Regulamenta a Lei n. 9.795, de 27 de abril de 1999, que institui a Política Nacional de Educação Ambiental, e dá outras providências. Brasília: Casa Civil, 
2002. Disponível em: <http://www.planalto.gov.br/ccivil_03/decreto/2002/d4281.htm>. Acesso em: 24 jun. 2019.

BRASIL. Ministério do Meio Ambiente. Histórico Mundial. Brasília: Portal do MMA, [2003]. Disponível em: <https://antigo.mma.gov.br/educacao-ambiental/pol\%C3\%ADtica-nacional-deeduca\%C3\%A7\%C3\%A3o-ambiental/historico-mundial.html>. Acesso em: 14 jul. 2021.

BRASIL. Medida Provisória n. 366, de 26 abril de 2007. Dispõe sobre a criação do Instituto Chico Mendes de Conservação da Biodiversidade - Instituto Chico Mendes, e dá outras providências. Brasília: Casa Civil, 2007a. Disponível em: <http://www.planalto.gov.br/ccivil_03/_Ato20072010/2007/Mpv/366.htm>. Acesso em: 21 jun. 2019.

BRASIL, Lei 11.516, de 28 agosto de 2007. Dispõe sobre a criação do Instituto Chico Mendes de Conservação da Biodiversidade - Instituto Chico Mendes... e dá outras providências. Brasília: Casa Civil, 2007b. Disponível em: <http://www.planalto.gov.br/ccivil_03/_Ato2007-

2010/2007/Lei/L11516.htm>. Acesso em: 13 out. 2019.

BRASIL. Decreto n. 6.101, de 26 abril de 2007. Aprova a Estrutura Regimental e o Quadro Demonstrativo dos Cargos em Comissão e das Funções Gratificadas do Ministério do Meio Ambiente, e dá outras providências. Brasília: Casa Civil, 2007c. Disponível em:

<http://www.planalto.gov.br/ccivil_03/_Ato2007-2010/2007/Decreto/D6101.htmimpressao.htm\#art5>. Acesso em: 23 jun. 2019.

BRASIL, Ministério do Meio Ambiente. Relatório de Gestão 2007 a julho de 2008. Brasília, DF: MMA, 2008. Disponível em:

<http://www.mma.gov.br/estruturas/educamb/_arquivos/20_03092008043402.pdf 1>. Acesso em: 23 jun. 2019.

BRASIL. Governo do Brasil. Acordos globais. Portal Governo do Brasil. Brasília, 23 jan. 2012. Disponível em: <http://www.brasil.gov.br/noticias/meio-ambiente/2012/01/acordos-globais>. Acesso em: 08 abr. 2019.

BRASIL. Ministério do Meio Ambiente. Marcos Legais \& Normativos: Documentos de Referência para o Fortalecimento da Política e do Programa Nacional de Educação Ambiental PRONEA. Brasília: Ministério do Meio Ambiente/Ministério da Educação, 2014.

BRASIL. Ministério do Meio Ambiente. Marcos Legais \& Normativos. 5 ed. [recurso eletrônico]. Brasília: MMA/MEC, 2018. Disponível em: <www.mma.gov.br/.../educacao-ambiental/.../98pronea.html?...de-educação-ambiental.. >. Acesso em: 17 mar. 2019.

BRASIL. Decreto n. 9.665, de 2 de janeiro de 2019. Aprova a Estrutura Regimental e o Quadro Demonstrativo dos Cargos em Comissão e das Funções de Confiança do Ministério da Educação... Brasília: Casa Civil, 2019a. Disponível em: <http://www.planalto.gov.br/ccivil_03/_Ato20192022/2019/Decreto/D9665.htm>. Acesso em: 08 abr. 2019.

BRASIL. Decreto n. 9.672, de 2 de janeiro de 2019. Aprova a Estrutura Regimental e o Quadro Demonstrativo dos Cargos em Comissão e das Funções de Confiança do Ministério do Meio Ambiente... Brasília: Casa Civil, 2019b. Disponível em: <http://www.planalto.gov.br/ccivil_03/_ato2019-2022/2019/decreto/D9672.htm>. Acesso em: 21 jun. 2019.

BRASIL. Lei 13.844, de 18 junho de 2019. Estabelece a organização básica dos órgãos da Presidência da República e dos Ministérios... Brasília: Casa Civil, 2019c. Disponível em: 
<http://www.planalto.gov.br/ccivil_03/_ato2019-2022/2019/Lei/L13844.htm>. Acesso em: 21 jun. 2019.

BRASIL. Medida Provisória n. 870, de 1 janeiro de 2019. Estabelece a organização básica dos órgãos da Presidência da República e dos Ministérios. Brasília: Casa Civil, 2019d. Disponível em: <http://www.planalto.gov.br/ccivil_03/_ato2019-2022/2019/Mpv/mpv870impressao.htm>. Acesso em: 21 jun. 2019.

BRASIL. Decreto n. 10.195, de 30 de dezembro de 2019. Aprova a Estrutura Regimental e o Quadro Demonstrativo dos Cargos em Comissão e das Funções de Confiança do Ministério da Educação... Brasília: Casa Civil, 2019e. Disponível em: < http://www.planalto.gov.br/ccivil_03/_ato20192022/2019/decreto/D10195.htm>. Acesso em: 12 jul. 2021.

BRASIL. Decreto n. 10.234, de 11 de fevereiro de 2020. Aprova a Estrutura Regimental e o Quadro Demonstrativo dos Cargos em Comissão e das Funções de Confiança do Instituto Chico Mendes... Brasília: Casa Civil, 2020a. Disponível em: <http://www.planalto.gov.br/ccivil_03/_ato20192022/2020/decreto/D10234.htm>. Acesso em: 12 jul. 2020.

BRASIL. Decreto n. 10.455, de 11 de agosto de 2020. Aprova a Estrutura Regimental e o Quadro Demonstrativo dos Cargos em Comissão e das Funções de Confiança do Ministério do Meio Ambiente... Brasília: Casa Civil, 2020b. Disponível em: <http://www.planalto.gov.br/ccivil_03/_ato2019-2022/2020/decreto/D10455.htm>. Acesso em: 12 jul. 2020 .

CARIDE, J.A.; MEIRA, P.A. Educação Ambiental e Desenvolvimento Humano. Lisboa: Instituto Piaget, 2001.

CARRINGTON, D. The Anthropocene epoch: scientists declare dawn of human-influenced age. The Guardian - Geology, London, 29 ago. 2016. Environment. Disponível em: <https://www.theguardian.com/environment/2016/aug/29/declare-anthropocene-epoch-experts-urgegeological-congress-human-impact-earth>. Acesso em 07 abr. 2019.

CDHPF - Comissão de Direitos Humanos de Passo Fundo. Manifesto da Educação Ambiental. Passo Fundo: Portal CDHPF, 2019. Disponível em: <http://cdhpf.org.br/noticias/manifesto-da-educacaoambiental/>. Acesso em: 21 jun. 2019.

CRUTZEN, P. J. Geology of mankind. Nature International journal of Science, London, v. 415, p. 23, 2002. Disponível em: <https://www.nature.com/articles/415023a>. Disponível em: 04 abr. 2019.

CUMPLIDO, D.C.O; PRIETO, N.G. Educação Ambiental Escolar: Um Processo Contínuo na Formação do Cidadão Consciente. Coleciona: Fichário do Educador Ambiental, Brasília, v. 2, ano 2, p. 9-12, Mar./Abr. 2009. Disponível em: <

https://antigo.mma.gov.br/estruturas/educamb/_arquivos/coleciona5_20.pdf>. Acesso em: 09 jul. 2021

DA CONFERÊNCIA das Nações Unidas para o Meio Ambiente Humano, em Estocolmo, à Rio-92: agenda ambiental para os países e elaboração de documentos por Comissão Mundial sobre Meio Ambiente e Desenvolvimento. Jornal em discussão, Brasília, [2012?]. Home. Disponível em: $<$ http://www.senado.gov.br/noticias/Jornal/emdiscussao/rio20/a-rio20/conferencia-das-nacoes-unidaspara-o-meio-ambiente-humano-estocolmo-rio-92-agenda-ambiental-paises-elaboracao-documentoscomissao-mundial-sobre-meio-ambiente-e-desenvolvimento.aspx>. Acesso em: 29 ago. 2019.

DECISÃO do STF sobre a Lei do Instituto Chico Mendes. Importante decisão sobre o procedimento de aprovação das medidas provisórias. Entenda. Atualizada. Portal Dizer o Direito, 8 mar. 2012. 
Disponível em: <https://www.dizerodireito.com.br/2012/03/decisao-do-stf-sobre-lei-doinstituto.html>. Acesso em: 24 jun. 2019.

EDUCADORES ambientais denunciam extinção de setores ligados ao tema no governo Bolsonaro. Portal Sul 21, Porto Alegre, 8 jan. 2019. Geral. Disponível em: <https://www.sul21.com.br/ultimasnoticias/geral/2019/01/educadores-ambientais-denunciam-extincao-de-setores-ligados-ao-tema-nogoverno-bolsonaro/>. Acesso em: 10 jun. 2019.

FARIAS, V. Em Meio a Críticas Internacionais, Ministério do Meio Ambiente cria Secretaria para Amazônia. O Globo, Rio de Janeiro, 21 set. 2020. Sociedade, s.p. Disponível em:

$<$ https://oglobo.globo.com/sociedade/em-meio-criticas-internacionais-ministerio-do-meio-ambientecria-secretaria-para-amazonia-1-24651435>. Acesso em: 12 jul. 2021.

GLASSMAN, G. A Estrutura das leis. Guia do Estudante, São Paulo, 24 fev. 2017. Atualidades no Vestibular. (s.p). Disponível em: <https://guiadoestudante.abril.com.br/blog/atualidadesvestibular/entenda-a-estrutura-das-leis-brasileiras/>. Acesso em: 24 jun. 2019.

GÓMEZ GARCÍA, J. MANSERGAS LÓPEZ, J. Recursos para la educación ambiental. Materiales para educadores. 3 ed. Madrid: Editorial CCS, 2010. E-book Kindle.

GUPTA, K. R. Environmental Education in India. Nova Delhi: Atlantic Publishers \& Distributors, 2010. E-book Kindle.

ICMBIO - Instituto Chico Mendes de Conservação da Biodiversidade. Relatório de Gestão: exercício 2016. Brasília: Portal do ICMBio, 2016. Disponível em: < https://www.icmbio.gov.br/portal/images/stories/Acesso_Informacao/Auditorias/Relatorios_de_Gestao /Relatorio_de_Gestao_ICMBio_2016-TCU.pdf >. Acesso em: 10 jul. 2021.

ICMBIO - Instituto Chico Mendes de Conservação da Biodiversidade. Educação Ambiental: Relatório de Gestão 2016. Brasília: Portal do ICMBio, 2019a. Disponível em:

<http://www.icmbio.gov.br/educacaoambiental/images/stories/acoes/Relat\%C3\%B3rio_de_Gest\%C3 \%A3o_-_COEDU_2016_-_17_04_17.pdf >. Acesso em: 22. jun. 2019.

ICMBIO - Instituto Chico Mendes de Conservação da Biodiversidade. Diretrizes e Orientações Metodológicas para planejamento e implementação de processos de Educação Ambiental em Unidades de Conservação Federais e Centro de Pesquisa e Conservação do ICMBio. Brasília: Portal do ICMBio, 2019b. Disponível em: <

https://www.icmbio.gov.br/educacaoambiental/images/stories/biblioteca/Publica\%C3\%A7\%C3\%B5es _da_COEDU/PRODUTO_1_-

_Diretrizes_e_Orienta\%C3\%A7\%C3\%B5es_Metodol\%C3\%B3gicas_de_EA_em_UCs_FINAL.pdf>. Acesso em: 22. jun. 2019.

ICMBIO - Instituto Chico Mendes de Conservação da Biodiversidade. Educação Ambiental: Capacitação. Brasília: Portal do ICMBio, 2019c. Disponível em: <http://www.icmbio.gov.br/educacaoambiental/capacitacao.html>. Acesso em: 15 jun. 2021.

ICMBIO - Instituto Chico Mendes de Conservação da Biodiversidade. Educação Ambiental: O que fazemos. Brasília: Portal do ICMBio, 2019d. Disponível em:

<http://www.icmbio.gov.br/educacaoambiental/>. Acesso em: 22 jun. 2019.

IVAR, J. A era humana. Revista Pesquisa Fabesp. São Paulo, [s.v], ed. 243, [s.p], Mai. 2016. Disponível em: <http://revistapesquisa.fapesp.br/2016/05/19/a-era-humana/>. Acesso em: 07 abr. 2019. 
LIMA, G. F. C. Educação ambiental no Brasil. Campinas: Papirus, 2011. E-book Kindle.

LINO, G.L. Antropoceno: "era dos humanos" é mais política que científica. Portal Solidariedade Íbero-americana, 7 out. 2016. Ciência e Tecnologia. Disponível em:

<https://msiainforma.org/antropoceno-era-dos-humanos-e-mais-politica-que-cientifica/>. Acesso em: 07 abr. 2019.

LOUREIRO, C. F. B.; SAISSE, M. V., CUNHA, C.C. Histórico da educação ambiental no âmbito federal da gestão ambiental pública: um panorama da divisão do IBAMA à sua reconstrução no ICMBio. Desenvolvimento e Meio Ambiente, Curitiba, v. 28, 2013, p. 57-73, Jul./Dez. 2013. Disponível em: <https://revistas.ufpr.br/made/article/view/30204>. Acesso em: 21 jun. 2019.

LOUREIRO, C. F. B.; SAISSE, M. Educação ambiental na gestão ambiental pública brasileira: uma análise da SEMA ao ICMBio. Revista de Educação Pública, Cuiabá. v. 23, n. 52, p. 105-129, Jan./Abr. 2014. Disponível em:

<https://www.sigam.ambiente.sp.gov.br/sigam3/Repositorio/472/Documentos/Mural_PlanosdeFiscaliz acao/FormacaoSocioambiental/Referencias/Educacao\%20ambiental\%20na\%20gestao\%20ambiental\% 20publica\%20brasileira\%20LOUREIRO.pdf>. Acesso em: 21 jun. 2019.

LOURENÇO, J. C. Educação Ambiental na Prática: conceitos e aplicações. Campina Grande: Edição Independente, 2018. E-book Kindle.

LUZ, L. M.; MARCAL, M.S. A perspectiva geográfica do Antropoceno. Revista de Geografia, Recife, v. 33, n. 2, p. 143-160, 2016. Disponível em:

<https://periodicos.ufpe.br/revistas/revistageografia/article/view/229251>. Acesso em: 04 abr. 2019.

MACHADO, J. T. M. Educação ambiental: um estudo sobre a ambientalização do cotidiano escolar. 2014. 245f. Tese (Doutorado em Ciências) - Universidade de São Paulo, Piracicaba, 2014. Disponível em: <https://www.teses.usp.br/teses/disponiveis/91/91131/tde-07072014-

114108/publico/Julia_Teixeira_Machado_versao_revisada.pdf>. Acesso em: 1 abr 2019.

MACHADO, R. Em meio à crise ambiental, Ministério cria oficialmente Secretaria para a Amazônia. Folha de São Paulo, São Paulo, 21 set. 2020. Ambiente, s.p. Disponível em:

$<$ https://www1.folha.uol.com.br/ambiente/2020/09/em-meio-a-crise-ambiental-ministerio-criaoficialmente-secretaria-para-a-amazonia.shtml>. Acesso em: 12 jul. 2020.

MARQUESAN, F. F. S.; FIGUEIREDO, M. D.; CONTRERAS, J. M. I; ZAMORA, D. T. Organização no Antropoceno: Reflexões Sobre o Avanço da Temática. In: CONGRESSO BRASILEIRO DE ESTUDOS ORGANIZACIONAIS, 5, 2018, Curitiba. Anais...Curitiba: SBEO, 2018. p. 1-7. Disponível em: <http://www.sisgeenco.com.br/sistema/cbeo/anais2018/ARQUIVOS-resumos/GT1665-168-20180720170953.pdf>. Acesso em: 07 abr. 2019.

MEDIA note: Anthropocene Working Group (AWG). Press Office, Leiscester, 29 ago. 2016. (s.p). Disponível em: <https://www2.le.ac.uk/offices/press/press-releases/2016/august/media-noteanthropocene-working-group-awg?>. Acesso em: 07 abr. 2019.

MELO, M. R.; BARCELOS, M. A. Concessão em parques nacionais federais: - Houve alteração após a publicação da Lei n⿳0 13.668 de 28 de maio de 2018 para a concessão de um parque nacional? Disponível em:< http://ava.icmbio.gov.br/mod/data/view.php?d=17\&filter=1\&rid=2847>. Acesso em: 09 jul. 2021.

MESQUITA, J. L. ICMBio apequenado por Ricardo Salles, o Algoz do MMA. Portal Mar sem Fim, São Paulo, 14 maio 2020. Opinião. Disponível em: <https://marsemfim.com.br/icmbio-apequenadopor-ricardo-salles-algoz-mma/>. Acesso em: 05 out. 2020. 
NASSIF, L. Manifesto da Educação Ambiental alerta para grave desmonte. Jornal Ggn, [S.1.], 08 jan. 2019. Meio Ambiente. (s.p.). Disponível em: <https://jornalggn.com.br/meio-ambiente/manifesto-daeducacao-ambiental-alerta-para-grave-desmonte/>. Acesso em: 21 jun. 2019.

NAVARRO, R. F. A Evolução dos Materiais. Parte1: da Pré-história ao Início da Era Moderna. Revista Eletrônica de Materiais e Processos, Campina Grande, v. 1, n. 1, p. 1-11, 2006. Disponível em: <https://aplicweb.feevale.br/site/files/documentos/pdf/32246.pdf>. Acesso em: 31 ago. 2019.

OBSERVARE - Observatório da Educação Ambiental. Manifesto da educação ambiental. [S.1]: Observare, 2019. Disponível em: <https://observatorioea.blogspot.com/2019/01/manifesto-daeducacao-ambiental.html>. Acesso em: 1 abr. 2019.

ONU - Organização das Nações Unidas. A ONU e o meio ambiente. Brasília: ONU/Brasil, 16 set. 2020. Disponível em: <https://brasil.un.org/pt-br/91223-onu-e-o-meio-ambiente>. Acesso em: 09 jul. 2021.

ORTEGA, M. A. A. Educación Ambiental: Crónica de un proceso de formación. Madrid: Newton. Edición y Tecnología Educativa, 2016. E-book Kindle.

PÁDUA, J. A. As bases teóricas da história ambiental. Estudos Avançados, São Paulo, v. 24, n. 68, p. 81-101, 2010. Disponível em: <http://www.scielo.br/scielo.php?script=sci_arttext\&pid=S010340142010000100009\&lng=en\&nrm=iso>. Acesso em: 31 mar. 2019.

PAGLIOLI, F. S. Técnica Legislativa, [s.1] [200?].59 slides: color. Disponível em: <http://www2.al.rs.gov.br/escola/LinkClick.aspx?fileticket=5XI_7pSd2pA\%3D\&tabid=6318>. Acesso em: 24 jun. 2019.

PARO, D. "Divisão do Ibama causa polêmica em Foz". Gazeta do Povo, Curitiba, 19 jun. 2007. Vida e Cidadania, (s.p.). Disponível em: <https://www.gazetadopovo.com.br/vida-e-cidadania/divisao-doibama-causa-polemica-em-foz-ainssci8234249pnlnp8std1q/>. Acesso em: 21 jun. 2019.

PHILIPPI JR. A., MALHEIROS, T. F. Saúde Ambiental. In: PHILIPPI JR. A., PELICIONI M.C.F. (Ed.). Educação ambiental e sustentabilidade. 2 ed. rev. e atual. Barueri: Manole, 2014. p. 57-84.

PINTO, M. Reportagem Especial: Porque a proposta de divisão do Ibama tem que ser melhor discutida com a sociedade. Ambiente Brasil, [Curitiba], 22 jun. 2007. (s.p). Disponível em:

$<$ https://noticias.ambientebrasil.com.br/exclusivas/2007/06/22/31868-reportagem-especial-por-que-aproposta-de-divisao-do-ibama-tem-que-ser-melhor-discutida-com-a-sociedade.html >. Acesso em: 21 jun. 2019.

PYNE, S. J. Fire and Earth: creating combustion. In: PYNE, S. J. Fire: a brief history. Seattle: University of Washington Press, 2001. p. 3-24.

REBEA - Rede Brasileira de Educação Ambiental. Carta aberta ao Ministro do Meio Ambiente. Brasília: Portal REBEA, 2019a. Disponível em: <https://www.rebea.org.br/images/conteudo/NOTA_REBEA_FINAL_v09-01-2019.pdf>. Acesso em: 10 jun. 2019.

REBEA - Rede Brasileira de Educação Ambiental. MANIFESTO das CIEAS do Brasil sobre a Educação Ambiental. Brasília: Portal REBEA, 2019b. Disponível em:

$<$ https://www.rebea.org.br/index.php/noticias/88-noticias/156-manifesto-das-cieas-do-brasil-sobre-aeducacao-ambiental>. Acesso em: 10 jun. 2019. 
REIGOTA, M. O que é educação ambiental. São Paulo: Brasiliense, 1994 (Coleção Primeiros Passos 292) E-book Kindle.

REDIN, M. et al. Impactos da queima sobre atributos químicos, físicos e biológicos do solo. Ciência Florestal, Santa Maria, v. 21, n.2, p. 381-392, 2011. Disponível em:

<https://periodicos.ufsm.br/cienciaflorestal/article/view/3243/1884>. Acesso em: 27 mar. 2019.

ROHDE, G. M. Epistemologia Ambiental. 2 ed. Porto Alegre: EDIPUCRS, 2005. (Coleção Filosofia 37). Disponível em:

<https://books.google.com.br/books?id=P3E4DKuzddAC\&printsec=frontcover\&hl=pt-

PT\&source $=g b s \_a t b \# v=$ onepage $\& q \& f=$ false $>$. Acesso em: 07 abr. 2019.

RODRIGUES, C. G. O; GODOY, L. R. C. Atuação pública e privada na gestão de Unidades de Conservação: aspectos socioeconômicos da prestação de serviços de apoio à visitação em parques nacionais. Desenvolvimento e Meio Ambiente, Curitiba, v. 28, 2013, p. 75-88, Jul./Dez. 2013. Disponível em: <https://revistas.ufpr.br/made/article/view/31280>. Acesso em: 07 out. 2020.

RODRIGUES, C. G. O.; ABRÚCIO, F. L. Parcerias e concessões para o desenvolvimento do turismo nos parques brasileiros: possibilidades e limitações de um novo modelo de governança. Revista Brasileira Pesquisa em Turismo, São Paulo, v. 13, n. 3, p. 105-120, Dez. 2019. Disponível em: $<$ http://www.scielo.br/scielo.php?script=sci_arttext\&pid=S198261252019000300105\&lng=en\&nrm=iso >. Acesso em: 07 out. 2020.

RODRIGUES, M. O Antropoceno em disputa. Ciência e Cultura, São Paulo, v. 69, n. 1, p. 19-22, Mar. 2017. Disponível em: <http://cienciaecultura.bvs.br/scielo.php?script=sci_arttext\&pid=S000967252017000100010\&lng=en\&nrm=iso>. Acesso em: 07 abr. 2019.

RODRIGUES, S.C.M et al. Os Recursos Naturais no Processo de Desenvolvimento Econômico Capitalista: Uma Breve Reflexão. Semioses: Inovação, Desenvolvimento e Sustentabilidade, Rio de Janeiro, v. 13, n. 4, p. 50-68, Out./Dez. 2019. Disponível em:< https://revistas.unisuam.edu.br/index.php/semioses/article/download/433/217/>. Acesso em: 10 jul. 2021.

SAISSE, M. V. Sentidos e práticas da educação ambiental no Brasil: as unidades de conservação como campo de disputa. In: EPEA - ENCONTRO PESQUISA EM EDUCAÇÃO AMBIENTAL, 7, 2013. Rio Claro. Anais... Rio Claro: UNESP, 2013. p.1-16. Disponível em: <http://www.epea.tmp.br/epea2013_anais/pdfs/plenary/0094-1.pdf>. Acesso em 22 jun. 2019.

SAISSE, M. V; LOUREIRO, C. F. B. Histórico da educação ambiental no âmbito federal da gestão ambiental pública: um panorama desde a Sema ao ICMBio. Rio de Janeiro: Portal do Núcleo de Referência em Educação Ambiental, [2013?] Disponível em: <http://nuredam.com.br/files/divulgacao/artigos/Artigo\%20EA\%20Maryane\%20Loureiro.pdf >. Acesso em: 23 jun. 2019.

SANTOS, P. R et al. Breve análise da importância dos órgãos executores da política ambiental brasileira frente aos agravos ambientais em unidades de conservação. Revista Brasileira de Gestão Ambiental e Sustentabilidade, João Pessoa, v. 7, n.15, p. 211-223, 2020. Disponível em: <http://revista.ecogestaobrasil.net/v7n15/v07n15a15a.html>. Acesso em: 15 jun. 2021.

SCHIMIDT, L.; NAVE, J. G.; GUERRA, J. Educação Ambiental. Balanço e perspectivas para uma agenda mais sustentável. Lisboa: Imprensa de Ciências Sociais/Instituto de Ciências Sociais da Universidade de Lisboa, 2010. E-book Kindle. 
PORTAL MÁRCIO AYRES. Prêmio Marcio Ayres para Jovens Naturalistas. Seja um Jovem Naturalista do Século XXI. Belém: Portal Márcio Ayres, 2021. Disponível em: $<$ http://marcioayres.museugoeldi.br/index.php?option=com_content\&view=article\&id=4\&Itemid=4>. Acesso em 12 jul. 2021.

SILVINO, A. Concessão de Parques Nacionais à iniciativa privada: é possível garantir preservação? [Entrevista concedida a] VIANA, B. Brasil de Fato. Fortaleza, 14 jan de 2020. Geral, (s.p). Disponível em: <https://www.brasildefato.com.br/2020/01/14/concessao-de-parques-nacionais-a-iniciativaprivada-e-possivel-garantir-preservacao >. Acesso em: 07 out. 2020.

SOFFIATI. A. Do global ao local: reflexões sobre o Ecologismo e Eco-história. Rio de Janeiro: Autografia (Livros Digitais), 2016.

SOUSA, M. S.; CARMO, R. R., ROCHA, S. M. Rio + 10: a influência da Rio 92 e os reflexos da conferência na política Mundial. In: CONGRESSO INTERNACIONAL DE DIREITO AMBIENTAL, 2, 2013, Santos. Anais... Santos: Editora Universitária Leopoldianum, 2013. p 179-206. Disponível em: <https://www.unisantos.br/wp-content/uploads/2018/08/direito-ambiental-completo.pdf >. Acesso em: 08 jul. 2021.

STEFFEN, W.; CRUTZEN, P. J.; McNEILL, J. R. The Anthropocene: Are Humans Now Overwhelming the Great Forces of Nature? Ambio, Stockholm, v. 36, n. 8, p. 614-621, Dez. 2007. Disponível em: <https://openresearchrepository.anu.edu.au/bitstream/1885/29029/2/01_Steffen_The_Anthropocene\%3a_Are_Humans_200 7.pdf >. Acesso em: 08 jul. 2021.

STF mantém Instituto Chico Mendes, mas dá dois anos para Congresso editar nova lei sobre a autarquia. Portal do Supremo Tribunal Federal. Brasília, 7 de março de 2012. Disponível em: $<$ http://www.stf.jus.br/portal/cms/verNoticiaDetalhe.asp?idConteudo=202057>. Acesso em: 24 jun. 2019.

TILIO NETO, P. Ecopolítica das mudanças climáticas o IPCC e o ecologismo dos pobres. Rio de Janeiro: Centro Edelstein de Pesquisas Sociais, 2010. Disponível em: <https://static.scielo.org/scielobooks/x9z8z/pdf/tilio-9788579820496.pdf>. Acesso em: 09 jul. 2021.

UNITED Nations Conference on Environment and Development (UNCED), Earth Summit. Sustainable Development Goal Knowledge Platform. [1992?]. Disponível em: <https://sustainabledevelopment.un.org/milestones/unced>. Acesso em: 31 mar. 2019.

VALPORTO, O. Ministério do Meio Ambiente caminha para extinção por inanição de recursos. Portal \#Colabora, [s.1], 15 set. 2020. Meio Ambiente, s.p. Disponível em: <https://projetocolabora.com.br/ods13/ministerio-do-meio-ambiente-caminha-para-extincao-porinanicao-de-recursos/>. Acesso em: 13 jul. 2021.

VEIGA, J. E. A Primeira Utopia do Antropoceno. Ambiente e Sociedade, São Paulo, v. 20, n. 2, p. $227-$ 246, jun. 2017. Disponível em: <http://www.scielo.br/scielo.php?script=sci_arttext\&pid=S1414753X2017000200227\&lng=pt\&nrm=iso >. Acesso em: 08 abr. 2019.

VIOLA, E.; BASSO, L. O Sistema internacional do Antropoceno. Revista Brasileira de Ciências Sociais, São Paulo, v. 31, n. 92, p. 1-18, 2016, Disponível em: <http://www.scielo.br/pdf/rbcsoc/v31n92/0102-6909-rbcsoc-3192012016.pdf>. Acesso em: 07 abr. 2019. 